\title{
Editors of the Archives
}

$\begin{array}{ll}\text { Hugh Thursfield and Reginald Miller } & 1926-33 \\ \text { Charles Harris and Alan Moncrieff } & 1934-38 \\ \text { Alan Moncrieff and Richard Ellis } & 1939-45 \\ \text { Richard Ellis } & 1946-47 \\ \text { Richard Ellis and Philip Evans } & 1948-49 \\ \text { Philip Evans and Ian Cathie } & 1950-54 \\ \text { Ian Cathie and Richard Dobbs } & 1954-63 \\ \text { Richard Dobbs and Douglas Gairdner } & 1964-69 \\ \text { Douglas Gairdner and Roger Robinson } & 1969-79 \\ \text { Roger Robinson and Roy Meadow } & 1979-82 \\ \text { Roy Meadow and Bernard Valman } & 1982-\end{array}$

\section{Hugh Thursfield (1869-1944)}

From Trinity College, Oxford, where he took a First in Mods he went to St Bartholomew's Hospital and became a member of the staff. He was demonstrator of Morbid Anatomy for many years and published a popular book 'Medical Morbid Anatomy and Pathology'. Promotion at Bart's was apt to be slow and he was still an Assistant Physician in charge of the Children's Department when he retired. All his life he was a student of the Classics. To him the Odyssey was the finest story in the world and one that a wise man should read most nights for a while before going to bed. He played a major part in the production of a great paediatric textbook by Garrod, Batten, and Thursfield. Anyone in search of information would find that he could generally supply the answer, whether it concerned the signs of the Zodiac or the dates of all the editions of the Encyclopaedia Britannica. A bachelor, he had a great knowledge of food and how to serve it, and he was a fine judge of claret.

\section{Reginald Miller (1879-1948)}

He was appointed as a General Physician to St Mary's Hospital, London, although most of his paediatric work was done at the Paddington Green Children's Hospital. He wrote articles on coeliac disease and various forms of vomiting, but his special interest was in rheumatic diseases of childhood and he was the first in this country to establish a supervisory clinic for rheumatic children. As a young man, too young perhaps, he published a text

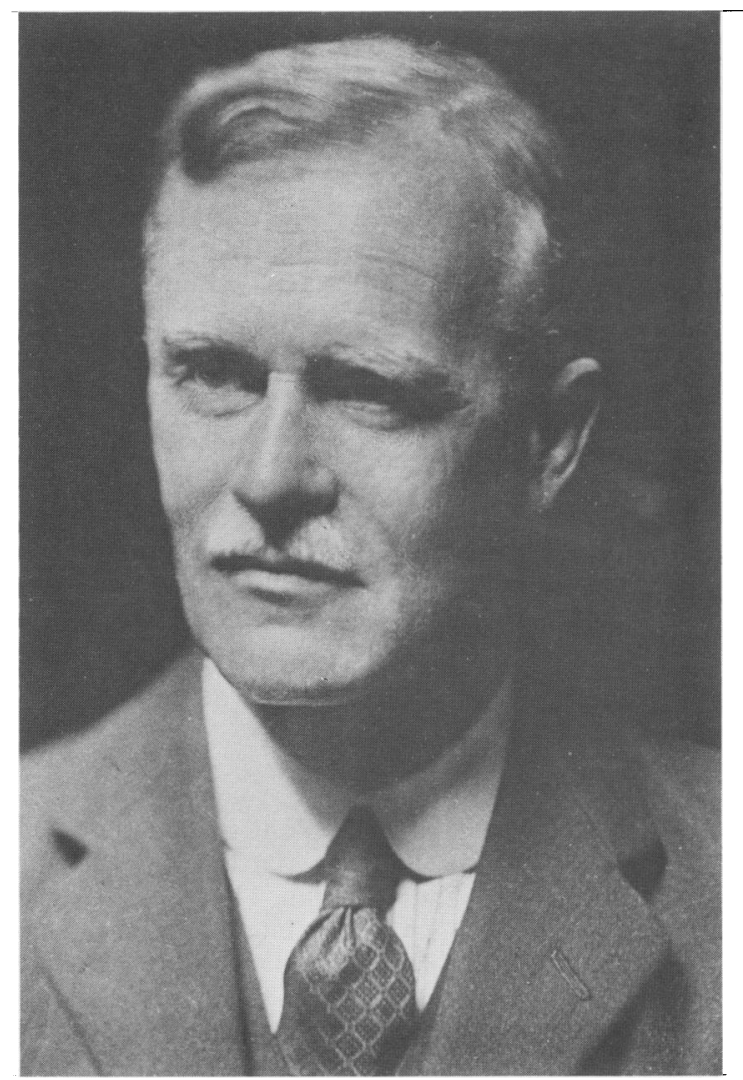

Hugh Thursfield 


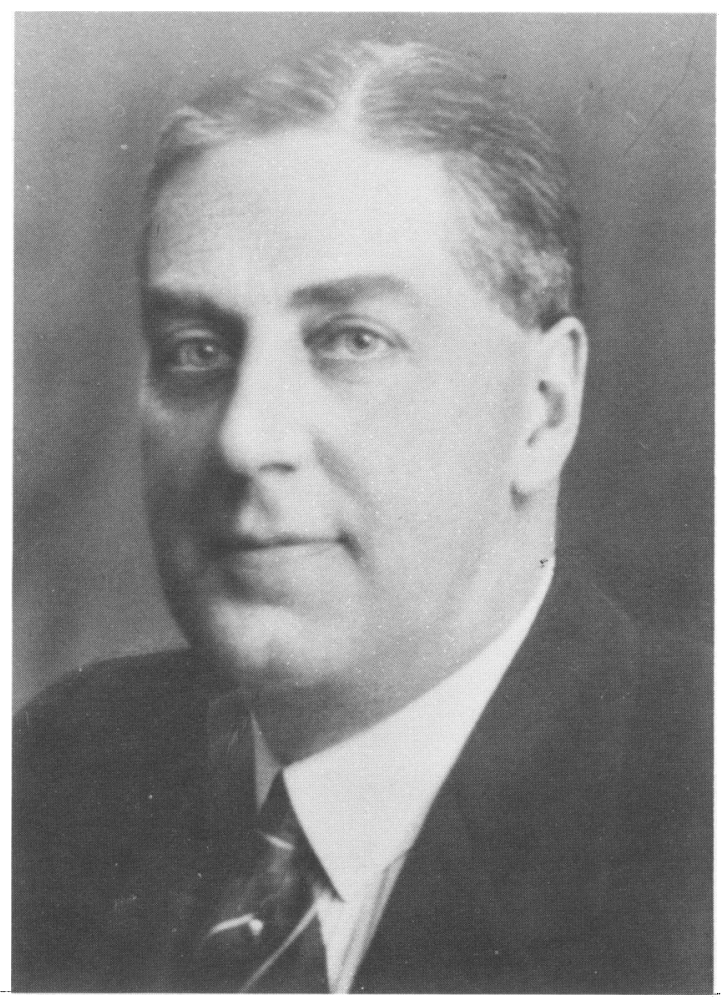

Reginald Miller

book 'The Medical Diseases of Children'. The reviewers deplored the lack of personal observation and he took their criticism to heart and refused a request for a second edition. He attended very few meetings of the British Paediatric Association and at committee meetings he generally kept silent. When he did speak, his carefully chosen comments or criticisms could be devastating. He was a master of words who wrote little and a wit who preferred to be alone.

\section{Sir Charles Harris (1900-1974)}

He was born in New York, spent his childhood in Australia, and qualified at St Bartholomew's Hospital. After a period at John Hopkins Medical School, Baltimore, he was appointed Assistant Physician at Bart's in 1928. The department at that time was represented only in outpatients; children who were inpatients were cared for by the general physicians. After a struggle a separate children's department with its own ward was achieved within a year. In addition he was Physician to the Westmins- ter Hospital for Children and Consultant Paediatrician to the London County Council. Harris was President of the British Paediatric Association in 1962.

He was a brilliant administrator and over 25 years ascended from Warden of the Medical College to Vice-Chancellor of London University. He held himself rather aloof and seemed to enjoy his ability to keep people guessing about his true beliefs. This could be carried to the extreme by opposing what he really wanted in the first round of a discussion.

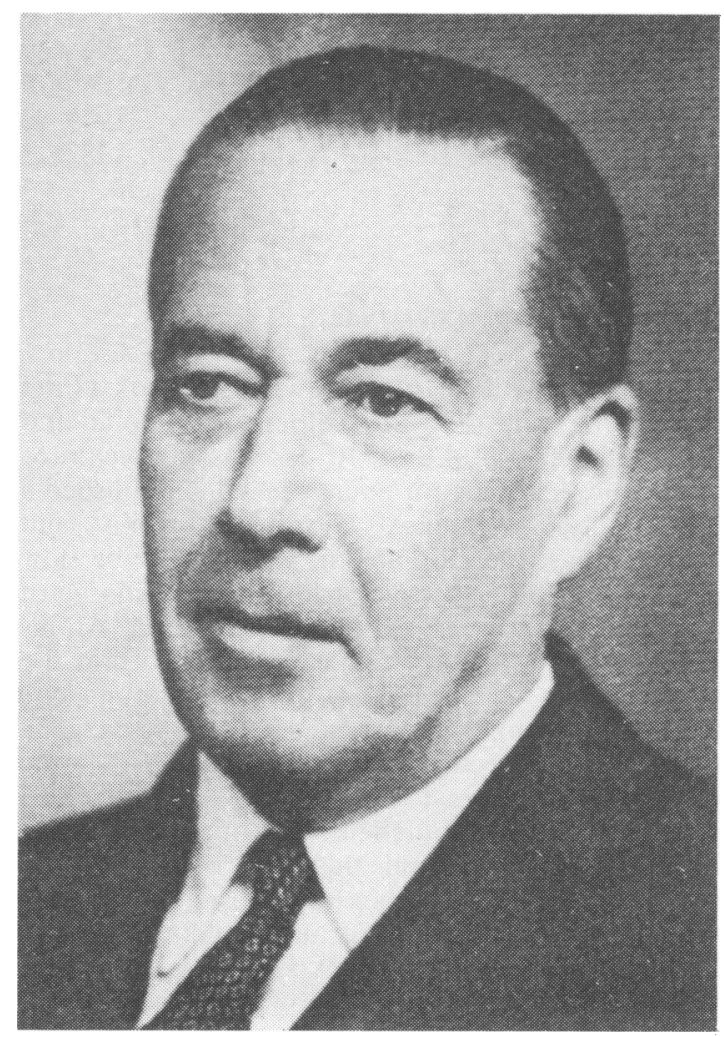

Sir Charles Harris

\section{Sir Alan Moncrieff (1901-1971)}

After various posts at the Middlesex Hospital and the Hospital for Sick Children, Great Ormond Street, between 1922 and 1934 he was appointed to the staff of both hospitals. In 1924 he had worked in Paris in the Health Division of the League of Red Cross Societies and in 1930 he studied in Germany 


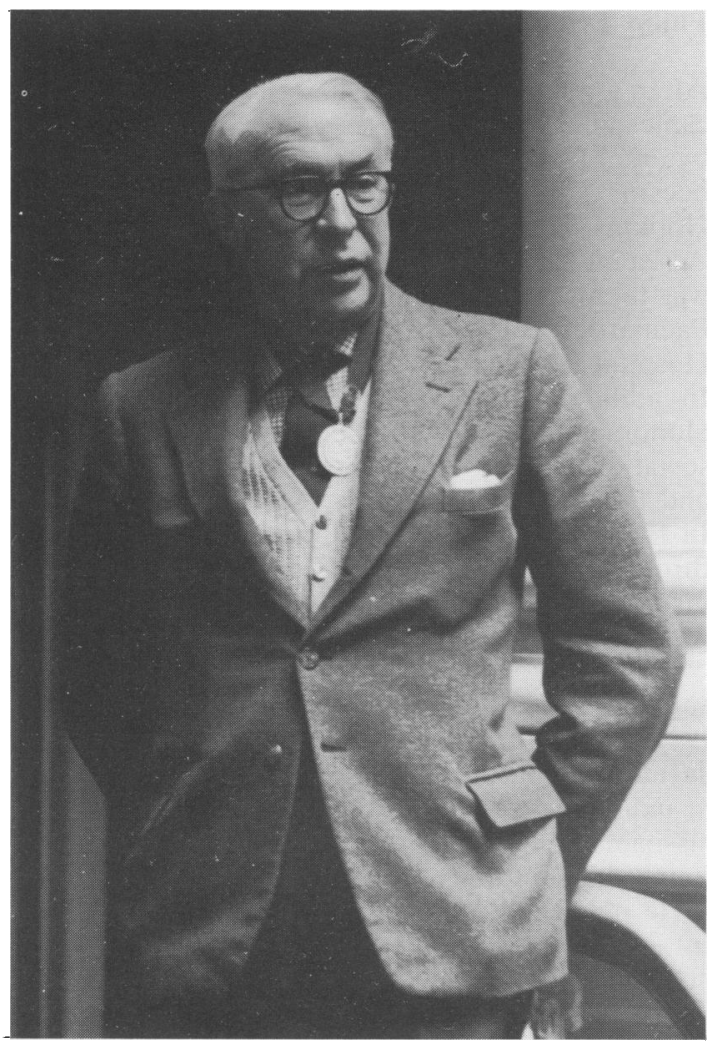

Sir Alan Moncrieff

with a Rockefeller Travelling Fellowship. His special interest was respiratory failure, including asphyxia in the newborn. He was also Paediatrician to Queen Charlotte's Maternity Hospital and Hammersmith Hospital and a part time School Medical Officer to the London County Council.

$\mathrm{He}$ was author of 'Child Health and the State' in 1953, Editor and part author of 'Text Book on the Nursing and Diseases of Sick Children', and joint Editor of 'Diseases of Children'. He wrote a hand book for The Practitioner on child health and was medical correspondent to The Times.

This would have been enough to occupy most men, but Moncrieff, with his capacity for concentration and genius for organising his working day, found time for many other activities. As a Justice of the Peace he worked in the Juvenile Courts in London and became chairman of many committees, including the Central Midwives' Board and the British Medical Association Journal Committee.
When the Institute of Child Health was founded at Great Ormond Street in 1946 Moncrieff was appointed to the first Nuffield Chair of Child Health. He incorporated an infant welfare centre as part of the Institute and established the Department of Growth and Development and the UNICEF Department of Tropical Medicine.

Moncrieff was the first holder of the James Spence Medal and was Honorary Secretary and later President of the British Paediatric Association.

\section{Richard Ellis (1902-1966)}

After two years at the Boston Children's Hospital where he was known as The English Doctor by his ruddy cheeked round face adorned with side whiskers he became Assistant Physician at Guy's with Hector Cameron. The Infant and Child Welfare Centre in the precincts of the hospital department introduced him to community child health. His spirit of service carried him with the Society of Friends to the Spanish Civil War where he arranged for the

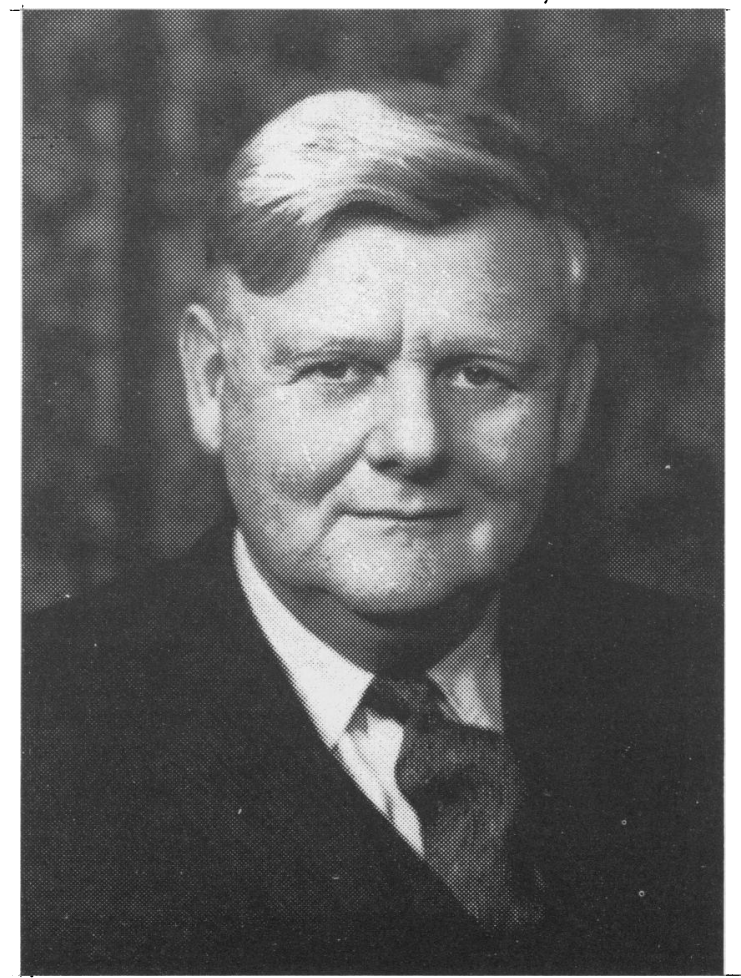

Richard Ellis 
evacuation of 4000 Basque children to Britain. In 1939 he was in Romania and Hungary caring for Polish refugees. He earned distinctions in the second world war through his long service in the RAF but also managed to find time to edit the Archives and to study the incidence of vitamin deficiencies in children and the natural history of the skeletal changes in early rickets.

In 1946 he became Professor of Child Life and Health in Edinburgh and the following year published 'Child Health and Development', which expressed his views on trying to improve child health gradually, emphasising the social, economic, and cultural aspects. This broad interest in child health contrasts with his earlier attraction to the rare and obtruse.

In 'Diseases in Infancy and Childhood' and 'Health in Childhood' he showed the undergraduate and family doctor how to prevent and manage diseases and what statutory and voluntary social services existed. He was President of the BPA in $1965-66$, but ill health prevented him from carrying out his duties.

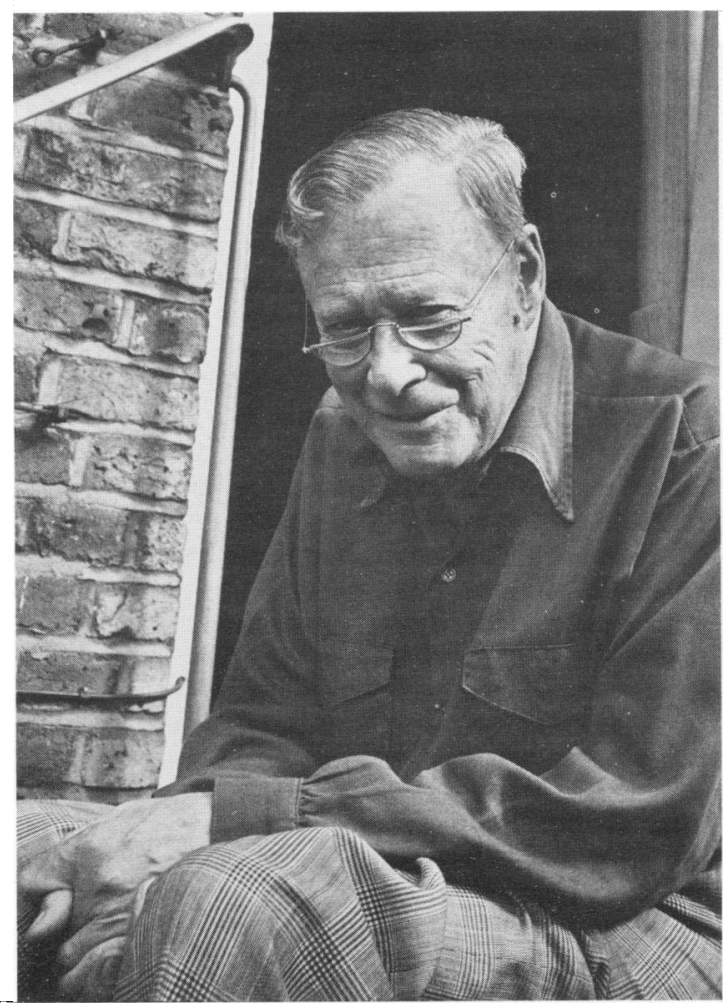

Philip Evans

\section{Philip Evans}

After graduating at Manchester University he became a Rockefeller Research Fellow at the Presbyterian Hospital, New York. The following year he became Director of the outpatient clinics at John Hopkins Hospital. Between 1939 and 1946 he was Assistant Physician at King's College Hospital and was then appointed Director of the Department of Paediatrics at Guy's Hospital and Physician at the Hospital for Sick Children, Great Ormond Street. In addition to his busy clinical practice he was Honorary Secretary to the British Paediatric Association, Censor of the Royal College of Physicians, and Director of the British Tay Sachs Foundation. In 1967-68 he won the admiration of paediatricians throughout the world as Director of the first British medical team in Saigon, which was ravaged by war.

His first research interests were in rheumatic fever and later pink disease followed by cerebral paľsy. In 1948 , meditating on the shore of Lake Zurich, he decided to concentrate on congenital disorders but he maintained his interest in general paediatrics and his name came to mind first when a paediatrician sought help with his own sick child.

He published 'Infant Feeding and Feeding Difficulties' with RC MacKeith and was the Joint Editor of the 1953 edition of Garrod, Batten, and Thursfield's 'Diseases of Children'. By 1978 he had published more than 55 original articles and 130 reviews and invited articles, including a series of 'Letters from London' in the American Journal of Diseases of Children.

He lives in retirement in St John's Wood, London.

\section{Ian Cathie}

Ian Cathie qualified at Guy's Hospital in 1932 and four years later was appointed Pathologist to the Christie Hospital and Holt Radium Institute in Manchester. In 1938 he was appointed Clinical Pathologist at The Hospital for Sick Children, Great Ormond Street, and remained there until he retired in 1958. His research interests included penicillin, when the ration for the whole hospital was 1 gram per month, and later streptomycin. Between 1950 and 1960 his laboratory was an international centre for the serological diagnosis of toxoplasmosis. $\mathrm{He}$ also published papers on haematology, bacteriology, and fibrinolysin.

He retired to Moreton-in-Marsh where he has been trying to breed homozygous Hereford bulls. 


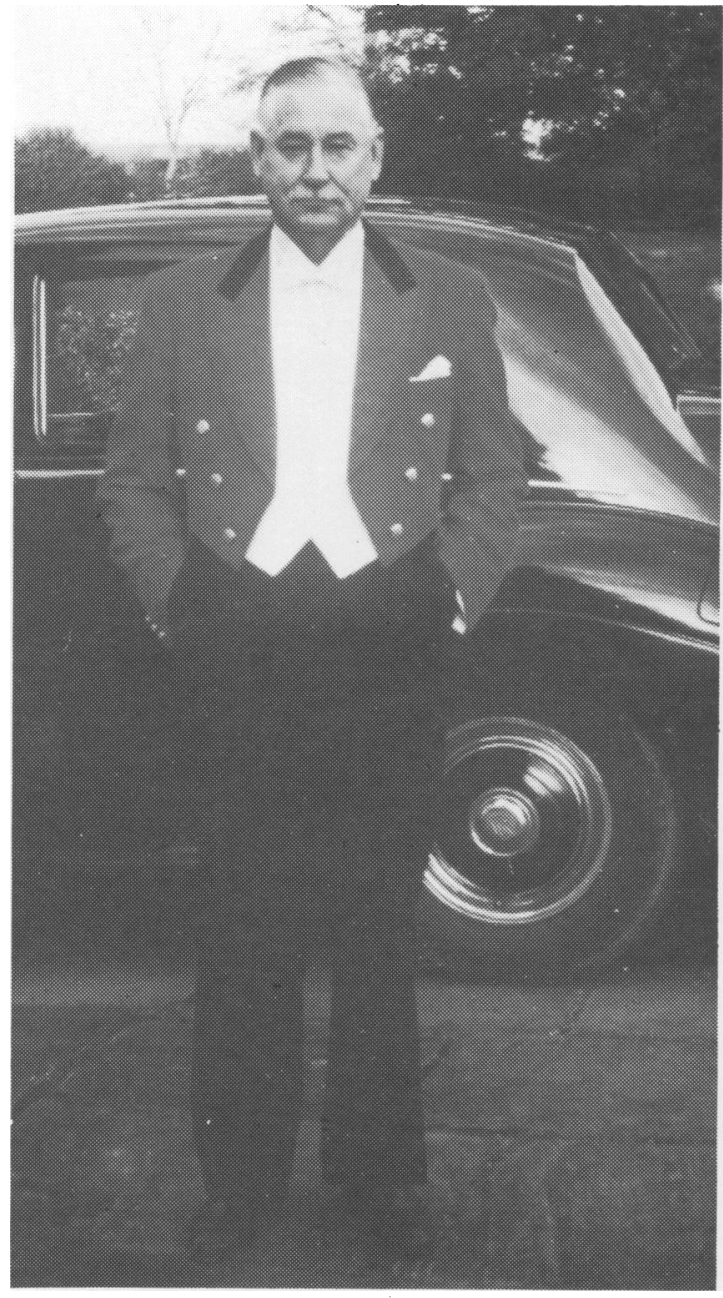

Ian Cathic
When a boy of 10 he had severe nephrotic syndrome and Sir Frederick Still was called in, who asked him what he intended to be when he grew up, and Richard replied 'I want to be a children's doctor like you, Sir'. Their next meeting occurred some 15 years later when Still examined him for the MRCP and was able to recall their earlier conversation.

In middle age he took up sailing and despite minimal experience sailed his 45 foot Natasha in ocean races. After his formal retirement he spent six months with the Grenfell Mission in Labrador before going to Nigeria as Professor of Paediatrics at Ahmadu Bello University, Zaria.

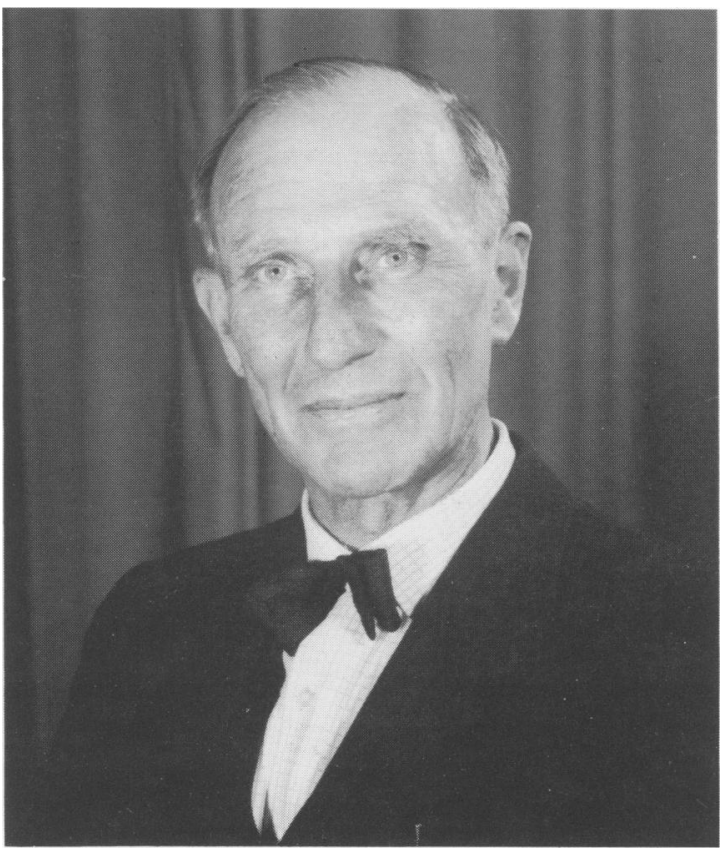

Richard Dobbs

\section{Douglas Gairdner}

Douglas Gairdner is still living in Cambridge where he worked as Consultant Paediatrician between 1948 and 1975. He went up to Oxford to read Chemistry but then changed to Medicine. After qualifying at the Middlesex Hospital and a two year post of Outpatient Registrar at Great Ormond Street he became a Fellow in Paediatrics at the Bellevue Hospital, New York, during 1939. During the war he served in the Royal Army Medical 
Corps, mainly in the Middle East, and then became First Assistant to Professor James Spence in Newcastle for three years.

His Doctor of Medicine thesis was on HenochSchönlein syndrome and his other research interests have included the nephrotic syndrome, blood formation in infancy, the pathogenesis and management of hyaline membrane disease, and the natural history of adipose cell development in children. 'The Fate of the Foreskin' written with Spence's encouragement remains a model of perceptive and pungent writing on the frontier of fact and fashion. Gairdner was the James Spence Medallist in 1976. He was Editor of the first four editions of 'Recent Advances in Paediatrics' and he still maintains his twin interests in sailing and writing by editing the Cruising Association's bulletin.

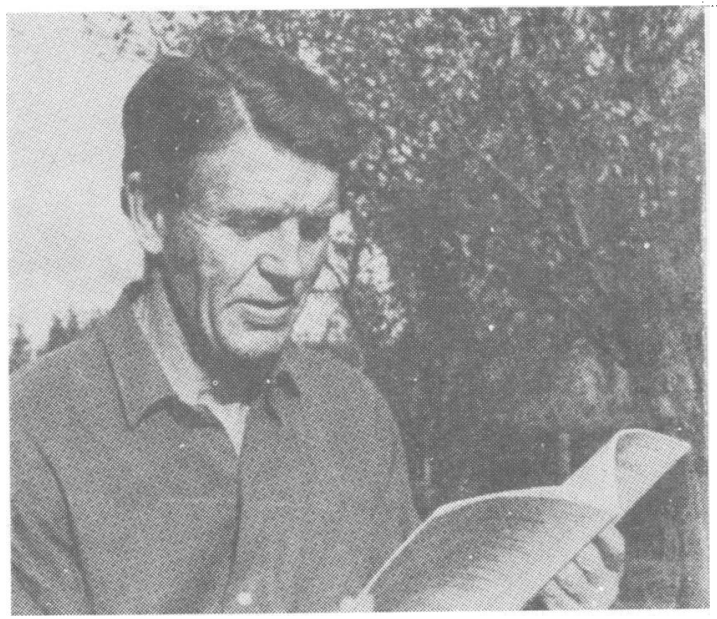

Douglas Gairdner

\section{Roger Robinson}

After Balliol College and the Radcliffe Infirmary in Oxford, he went to Hammersmith Hospital. He became Research Fellow in Boston and visiting Lecturer in Kentucky. Robinson returned to become Senior Lecturer at Hammersmith Hospital and then Consultant Paediatrician and four years

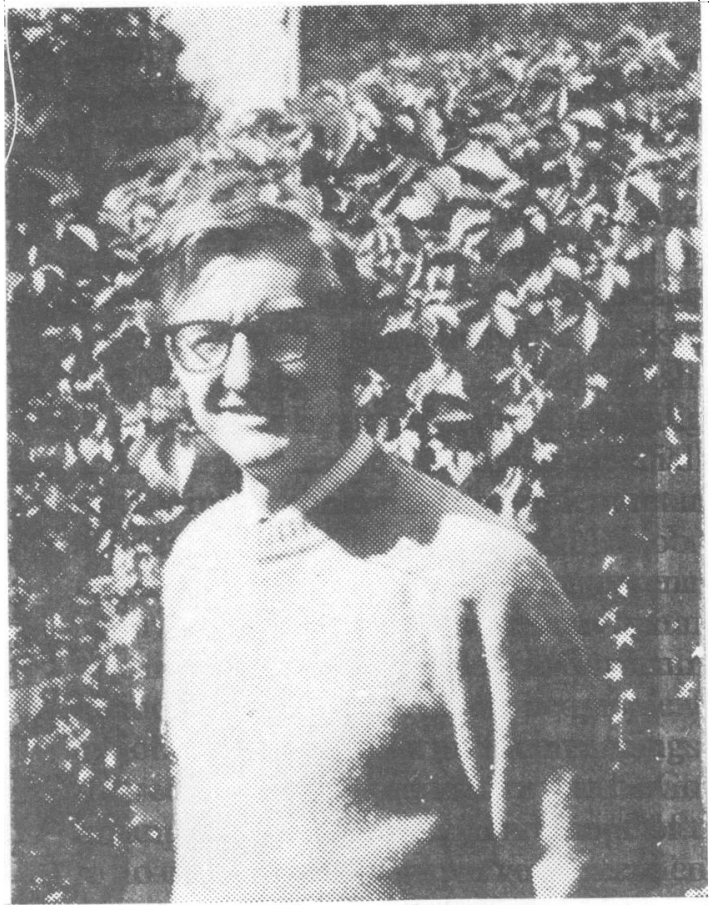

Roger Robinson

later the first Professor of Paediatrics at Guy's Hospital. He has kept a strong foot in general paediatrics as well as being a paediatric neurologist with special interests in language disorders, epilepsy, and the newborn. His earlier research was on carbohydrate metabolism and most of his later articles have been on neurology. He edited two books, 'Brain and Early Behaviour' and 'Congenital Malformations'. The general reader will remember him by his outstanding wisdom and clarity of thought in his leading articles in the Archives and British Medical Journal. 'The Whooping Cough Immunisation Controversy', 'Research Involving Children: Ethics, the Law and the Climate of Opinion', and 'The Child Who is Slow to Talk' are superb examples of the quality of his style.

BERNARD VALMAN 